\title{
Pemberdayaan Pemuda Karang Taruna Desa Ngentakrejo dalam Masa/Pasca Darurat Covid-19 Melalui Kegiatan Kesenian
}

\author{
Rahmawan Jatmiko, Ida Rochani Adi, Nur Saktiningrum \\ Fakultas Ilmu Budaya, Universitas Gadjah Mada \\ Korespondensi: rahmawan.jatmiko@ugm.ac.id
}

\begin{abstract}
This Community Service program is intended as one of assistance service programs for people affected by the Covid-19 pandemic, which has created major impacts on the pattern of people's lives in practically all aspects and levels of society, including the youth organizations in rural areas. This program focuses on facilitating activities which can maintain productivity and enthusiasm of the youths during the pandemicl post-pandemic situation. Some of the initial inputs and data of the youth group targeted for the activity, namely the youth organization Tunas Harapan Ngentakrejo, were obtained during the observation period which was then followed up for realization of the program. All of the activities in the program are carried out online or remotely, with internet communication media, by utilizing common communication technology devices, applications and software. This activity, conducted from July 2020 to mid-October 2020, has resulted in a collaborative video output featuring artistic activities produced youth organizations Tunas Harapan Ngentakrejo.
\end{abstract}

Keywords: artistic activities; assistance; community service; Covid-19; rural areas

\begin{abstract}
Abstrak
Program Pengabdian kepada Masyarakat ini ditujukan sebagai salah satu bentuk program pendampingan bagi masyarakat yang terdampak pandemi Covid-19 yang merupakan sebuah peristiwa yang berdampak besar bagi pola kehidupan masyarakat hampir di semua aspek dan lapisan masyarakat, tak terkecuali generasi muda di pedesaan, agar nantinya dapat menjaga produktivitas dan semangat dalam berkarya. Beberapa masukan awal dari kelompok pemuda sasaran kegiatan, yakni pemuda karang taruna Tunas Harapan Ngentakrejo, telah diperoleh pada masa observasi yang selanjutnya ditindaklanjuti sehingga terwujudlah program kegiatan ini. Keseluruhan kegiatan ini dilakukan dengan cara online atau jarak jauh, menggunakan media komunikasi via internet dan memanfaatkan perangkat-perangkat teknologi komunikasi serta beberapa software yang dapat digunakan untuk produksi karya bersama. Kegiatan yang dimulai sejak bulan Juli 2020 ini telah selesai dilaksanakan pada pertengahan Oktober 2020 dan mengasilkan luaran berupa hasil video kolaboratif yang menampilkan kegiatan kesenian dari para pemuda karang taruna Tunas Harapan.
\end{abstract}

Kata kunci: Covid-19; daerah pedesaan; kegiatan kesenian; pendampingan; pengabdian masyarakat 


\section{Pendahuluan}

Kegiatan organisasi atau kelompok pemuda di tingkat desa/kelurahan dan dusun merupakan salah satu yang merasakan dampak adanya pandemi Covid-19. Padahal, kegiatan kepemudaan tersebut memiliki peranan yang cukup penting dalam menjaga semangat dan produktivitas generasi muda serta memberikan dampak langsung maupun tidak langsung pada hubungan harmonis antara kelompok pemuda tersebut dan masyarakat sekitarnya. Hubungan harmonis tersebut merupakan salah satu faktor yang dapat memengaruhi semangat kerja (Dunggio, 2013:525).

Pada masa pandemi Covid-19 ini telah terlihat bahwa intensitas kegiatan pemuda, seperti halnya juga yang terjadi pada aspek-aspek lainnya, mengalami penurunan. Hal ini tentunya perlu menjadi perhatian berbagai pihak. Terlalu lama vakum dalam berkegiatan dan berdiam diri di rumah dapat berdampak kurang baik bagi perkembangan generasi muda tersebut.

Salah satu dampak negatif yang dapat muncul karena terlalu banyak tinggal di rumah, dalam hal ini, adalah berdiam diri tanpa kesibukan yang berarti, yaitu munculnya gejala yang dalam istilah medis disebut sebagai cabin fever atau demam kabin . Kondisi ini rentan terjadi selama kebijakan stay at home yang ditetapkan oleh pemerintah dan WHO untuk memutus mata rantai penyebaran virus Corona sejak sekitar bulan Maret tahun 2020. Salah satu cara untuk menghindari demam kabin adalah dengan menyalurkan hobi walaupun dengan cara yang berbeda karena keterbatasan untuk keluar rumah secara bebas.

Kegiatan yang cocok dilakukan untuk meminimalisasi dampak negatif demam kabin antara lain adalah bercocok tanam di halaman rumah, pekarangan atau lingkungan yang kecil, bermain dengan hewan peliharaan, membaca buku-buku yang menarik, memasak, atau menyanyi dan bermain alat musik. Selain itu, demam kabin dapat diatasi dengan tetap menjalin komunikasi dengan orang lain meskipun dengan cara yang berbeda, misalnya melalui video call atau aplikasi-aplikasi teknologi lain yang sudah banyak dijumpai, misalnya Zoom, Google Meet, ataupun Live Instagram. Kegiatan lain yang saat ini cukup marak adalah "Instajam" atau melakukan pertunjukan, misalnya musik atau drama, dengan cara menayangkan video kolaboratif menggunakan aplikasi video merging semacam Kinemaster.

Desa Ngentakrejo, Kecamatan Lendah, Kabupaten Kulon Progo bukan pertama kalinya mendapatkan pendampingan dari Universitas Gajah Mada. Sebelumnya, Kelurahan Ngentakrejo, yang berada di wilayah kecamatan Lendah, Kabupaten Kulon Progo juga pernah menjadi lokasi KKN PPM Universitas Gadjah Mada pada tahun 2018. Oleh karena itu, masyarakat di sana dapat menyambut baik program dan kegiatan pengabdian yang akan dilakukan dalam masa atau pascatanggap darurat Covid-19 ini dapat melengkapi atau meningkatkan hal-hal yang sudah dilakukan sebelumnya.

Kegiatan pengabdian ditargetkan pada generasi muda di Desa Ngentakrejo yang tergabung dalam karang taruna Tunas Harapan Kelurahan Ngentakrejo. Para pemuda yang tergabung dalam karang taruna tersebut sebelum adanya pandemi Covid-19 sudah dikenal cukup produktif seperti yang terlihat pada dokumentasi kegiatan karang taruna yang cukup rapi, misalnya pada akun media sosial Facebook KT Tunas Harapan. Karang taruna Tunas Harapan telah memiliki banyak kegiatan sebelum adanya pandemi, 
tetapi kemudian kegiatan-kegiatan itu menjadi tidak terlalu intens. Hal ini terlihat dari unggahan-unggahan dalam akun Facebook serta Instagram (IG) karang taruna Tunas Harapan, Ngentakrejo yang sangat sedikit pada masa-masa pandemi. Kurangnya kemeriahan kegiatan kepemudaan desa tersebut menjadi salah satu alasan dipilihnya tema kegiatan pengabdian ini.

Kegiatan pengabdian ini memiliki tiga tujuan pokok, yakni (1) mendampingi kegiatan karang taruna tingkat desa dan agar tetap produktif dalam berkegiatan meskipun dengan cara yang berbeda; (2) mempersiapkan langkah-langkah pemulihan akibat dampak pandemi, terutama menyangkut kegiatan-kegiatan yang bersifat fisik melalui diskusi, sambung rasa, dan penyuluhan dengan media daring (online); (3) memberdayakan para pemuda anggota karang taruna, terutama di rentang usia $17-25$ tahun, supaya dapat berkarya, berkreasi, dan berkesenian dengan memanfaatkan teknologi informasi secara lebih baik.

\section{Pendekatan Pelaksanaan Program}

Program ini adalah sebuah program pendampingan yang dilaksanakan sebagai salah satu langkah dalam memfasilitasi dan mendorong keberlanjutan program-program maupun kegiatan kelompok karang taruna yang telah ada, tetapi kegiatan-kegiatan tersebut terhenti atau berkurang intensitasnya karena dampak pandemi Covid-19. Program ini tidak bertujuan untuk memberikan sesuatu dalam bentuk fisik ataupun gagasan yang telah matang, tetapi lebih pada bentuk usaha untuk memberikan kiat-kiat dan motivasi maupun ide-ide pengembangan dari kegiatan atau program yang telah ada. Program ini secara sebagian menerapkan metode Participatory Rural Appraisal (PRA). Hamid (2018) mengemukakan bahwa salah satu prinsip dari PRA adalah penempatan masyarakat sebagai pelaku aktif atau pusat dari pelaksanaan program. Masyarakat tersebut berperan sebagai pihak yang mengeksekusi suatu program dengan fasilitator dari pihak luar, misalnya dari pihak kampus. Hamid menjelaskan bahwa suatu upaya pengembangan atau pembangunan dengan prinsip menempatkan masyarakat sebagai pusat (peoplecentered development) ini akan memberikan kebanggaan bagi masyarakat sasaran karena menjadikan mereka sebagai tuan di wilayahnya sendiri (Hamid, 2018:98). Masyarakat sasaran dalam program ini adalah kelompok pemuda karang taruna yang berperan penting sebagai penghubung antara pihak kampus pelaksana salah satu dari Tri Dharma Perguruan Tinggi, dalam hal ini adalah kegiatan Pengabdian kepada Masyarakat, dengan pihak kampus bertindak sebagai fasilitator kegiatan dan masyarakat pedesaan berperan sebagai tuan rumah yang mengeksekusi kegiatan. Setidaknya terdapat empat alasan atas difokuskannya program ini pada kelompok karang taruna, yakni sebagai berikut.

1. Kelompok karang taruna dipandang paling siap untuk melaksanakan kegiatan via daring, mengingat sebagian anggotanya adalah pemuda, yang merupakan kelompok usia yang paling terbiasa menggunakan teknologi komunikasi dan media sosial berbasis internet.

2. Kelompok karang taruna memiliki ketertarikan yang cukup besar untuk berinteraksi dengan pihak kampus (dosen dan mahasiswa).

3. Kelompok karang taruna memiliki Program Kerja (terbagi menjadi beberapa divisi/ bidang). 
4. Kelompok karang taruna memiliki media publikasi dan media sosial yang dapat dipantau untuk keberlanjutan atau keberhasilan kegiatan pemberdayaan.

Dalam konteks program pendampingan ini, Tim PKM telah melakukan observasi dan pemetaan mengenai program yang telah berjalan dan dilihat cocok maupun layak untuk dikerjakan sebagai upaya meminimalisasi dampak pandemi. Tim PKM melakukan diskusi awal dan kompromi untuk mempertemukan daftar skala prioritas yang telah disusun sebelumnya, untuk dicocokkan dengan daftar skala kebutuhan masyarakat sasaran, dalam hal ini adalah kelompok pemuda karang taruna Tunas Harapan, Kelurahan Ngentakrejo. Setelah diskusi awal tersebut, tahap-tahap pelaksanaan program dapat disusun sebagai berikut:

Tabel 1. Tahapan Pelaksanaan Program.

\begin{tabular}{|c|c|c|c|}
\hline \multicolumn{4}{|c|}{$\begin{array}{c}\text { Langkah Pelaksanaan Kegiatan Pengabdian kepada Masyarakat } \\
\text { oleh Tim FIB UGM di Desa Ngentakrejo Kulon Progo }\end{array}$} \\
\hline No & Reglatan & $\begin{array}{l}\text { Jadwal } \\
\text { Pellaksanaan }\end{array}$ & Pelaksana \\
\hline 1 & $\begin{array}{l}\text { Pendataan kegiatan Karang Taruna } \\
\text { Tunas Harapan yang berkaitan } \\
\text { dengan seni dan budaya }\end{array}$ & $\begin{array}{l}\text { Minggu ke } 3 \& 4 \\
\text { Juli }\end{array}$ & $\begin{array}{l}\text { Tim PKM FIB } \\
\text { UGM } \\
\text { KT Tunas } \\
\text { Harapan }\end{array}$ \\
\hline 2 & $\begin{array}{l}\text { Pertemuan/diskusi online panitia } \\
\text { pengabdian FIB UGM + mahasiswa } \\
\text { dengan peserta (anggota karang } \\
\text { taruna) }\end{array}$ & Minggu ke 4 Juli & $\begin{array}{l}\text { Tim PKM } \\
\text { UGM } \\
\text { KT Tunas } \\
\text { Harapan } \\
\text { Narasumber }\end{array}$ \\
\hline 4 & $\begin{array}{l}\text { Pelatihan singkat penggunaan } \\
\text { media dengan tujuan pembuatan } \\
\text { video kolaboratif }\end{array}$ & $\begin{array}{l}\text { Minggu ke-1 } \\
\text { Agustus }\end{array}$ & $\begin{array}{l}\text { Tim PKM } \\
\text { UGM } \\
\text { Narasumber }\end{array}$ \\
\hline 6 & $\begin{array}{l}\text { Lomba pembuatan video untuk } \\
\text { bahan video kolaboratif }\end{array}$ & $\begin{array}{l}\text { Agustus sd awal } \\
\text { September }\end{array}$ & $\begin{array}{l}\text { Tim PKM } \\
\text { UGM } \\
\text { KT Tunas }\end{array}$ \\
\hline 7 & $\begin{array}{l}\text { Evaluasi pembuatan video } \\
\text { Kolaboratif }\end{array}$ & awal September & $\begin{array}{l}\text { Tim PkM } \\
\text { UGM } \\
\text { KT Tunas } \\
\text { Harapan } \\
\text { Narasumber }\end{array}$ \\
\hline 8 & $\begin{array}{l}\text { Pengunggahan hasil video } \\
\text { kolaboratif ke IG Pengabdian } \\
\text { Masyarakat/ IG FIB UGM dan media } \\
\text { publikasi Karang Taruna Tunas } \\
\text { Harapan (IG dan Facebook) }\end{array}$ & $\begin{array}{l}\text { pertengahan- } \\
\text { akhir September }\end{array}$ & $\begin{array}{l}\text { Tim PKM } \\
\text { UGM } \\
\text { KT Tunas } \\
\text { Harapan }\end{array}$ \\
\hline
\end{tabular}

Sumber: Tim PKM

Tahapan-tahapan kegiatan tersebut di atas dijelaskan dan dibahas pada saat pertemuan pertama sekaligus perkenalan dengan seluruh anggota KT Tunas Harapan yang terlibat. Seluruh kegiatan di atas mulai dari tahapan observasi sampai pada penutupan program dilakukan via daring untuk meminimalisasi kontak fisik selama masa pandemi.

\section{Pelaksanaan Program}

Setelah diskusi awal, pelaksanaan program dapat dimulai dua minggu berikutnya dengan pembukaan program dan perkenalan, sarasehan daring sekaligus berbagi tip dan 
kiat-kiat dari narasumber, pelatihan singkat pembuatan video kolaboratif, dan proses pembuatan hingga penyuntingan video kolaboratif.

\section{Pembukaan Program dan Perkenalan Tim PKM dengan Anggota KT Tunas Harapan}

Pembukaan program diikuti oleh seluruh Tim PKM beserta mahasiswa yang terlibat, ketua, dan para anggota KT Tunas Harapan, khususnya dari bidang seni dan budaya. Dalam acara ini Tim PKM sebagai tamu memperkenalkan diri sekaligus memperkenalkan narasumber yang akan mengisi acara, yaitu Scholastika Berti. ${ }^{1}$ Narasumber bertugas mengisi acara selanjutnya, yaitu Sarasehan Daring dengan tema "Berkesenian di Masa Pandemi Agar Hidup Tetap Menyenangkan”.

Tabel 2. Daftar Nama Peserta dari Karang Taruna Tunas Harapan.

\begin{tabular}{|c|c|c|c|}
\hline No & Nama & Bakat seni & Jenis kelamin \\
\hline 1 & Desiyanto & Gitar & $\mathrm{L}$ \\
\hline 2 & Ardian Noor Fahad & Ketipung & $\mathrm{L}$ \\
\hline 3 & Febri Nurul Arifin & Vokal & $\mathrm{L}$ \\
\hline 4 & Pramudhika Robby Satrianta & drummer & $\mathrm{L}$ \\
\hline 5 & Agus Puryanto & Vokal & $\mathrm{L}$ \\
\hline 6 & Awanda Erna Lestari & Vokal & $\mathrm{P}$ \\
\hline 7 & Arman Yuliadi & Tari & $\mathrm{P}$ \\
\hline 8 & Medita Sekti Nur Sasti & Tari & $\mathrm{P}$ \\
\hline 9 & Guntari & Tari & $\mathrm{P}$ \\
\hline 10 & Parjianti Wahyuni & Vokal & $\mathrm{L}$ \\
\hline 11 & Nining Setyaningsih & Vokal & $\mathrm{P}$ \\
\hline 12 & Okta Suryani & vokal & $\mathrm{L}$ \\
\hline 13 & Agus Suryadi & Tari & \\
\hline 14 & Desy Wahyu Rahmawati & Vokal & \\
\hline 15 & Ari Kurnianto & & $\mathrm{P}$ \\
\hline
\end{tabular}

\section{Sarasehan Daring}

Sarasehan daring terdiri atas dua acara pokok, yakni pelatihan motivasi dan pelatihan serta kiat-kiat dalam pembuatan video kolaboratif. Untuk bagian pelatihan motivasi, narasumber berbagi pengalaman dan tip agar tetap aktif berkegiatan pada masa pandemi. Scholastika Berty alias Mbak Cacha sebagai narasumber memberikan saran-saran khusus, misalnya agar para pemuda dapat menjaga mood atau suasana hati dalam berkesenian di rumah sendiri, tetap produktif walaupun alat-alat yang digunakan tidak sebagus di studio. Para pemuda peserta pelatihan ini juga diharapkan dapat memanfaatkan sumber daya seperti pikiran, keterampilan yang telah dipunyai, dan alat yang ada dengan sebaik

1 Scholastika Berty AF adalah vokalis dari band asal Kulon Progo, "Roti dan Mentega", yang sudah sangat sering mengisi acara-acara di Yogyakarta dan sekitarnya. Ia juga penulis lagi yang berjudul "Damai Kulon Progo" sekaligus penggagas donasi untuk masyarakat terdampak Covid-19 bersama dengan Paguyuban Musisi Kulon Progo. 
mungkin, serta memanfaatkan kemajuan teknologi pada saat ini seperti gawai (gadget) dengan semaksimal mungkin. Mbak Cacha menyampaikan, "Kalau kita bisa menikmati sisi positif dari Covid-19 ini, kita bisa lebih mudah mendapat inspirasi." Hal ini dibuktikan sendiri oleh Mbak Cacha dengan diluncurkannya lagu (single) miliknya yang berjudul "Pertemuan dengan Angin" pada saat puncak pandemi ini. Tim PKM memandang pelatihan motivasi bagi para pemuda sebagai hal yang sangat penting, terutama pada saat pandemi seperti ini. Pelatihan motivasi tersebut bertujuan untuk membangkitkan potensi yang telah ada pada para pemuda. Menurut Munandar (2019), potensi yang telah ada pada masing-masing individu perlu dikembangkan secara maksimal dan potensi tersebut dapat dimaksimalkan dengan adanya kombinasi antara kesempatan, wawasan, motivasi, dan arahan yang tepat sasaran (Munandar dkk., 2019:24).

\section{Pelatiban Singkat Pembuatan Video Kolaboratif}

Pelatihan ini dilakukan dengan cara memberikan contoh-contoh video kolaboratif yang telah ada sebelumnya, baik yang sudah dipersiapkan oleh tim PKM maupun video-video yang dapat diakses secara bebas di media sosial dengan mengakses tautan atau tagar. Respons dari peserta cukup baik dan mereka terlihat sudah paham mengenai dasardasar pembuatan video karena sebelumnya telah mendapatkan pelatihan fotografi dan videografi. Pelatihan ini cukup singkat dan sebagian besar diisi dengan kegiatan tanya jawab antara peserta dan tim PKM. Ada pula partisipasi dari beberapa mahasiswa yang telah memiliki pengalaman pembuatan video dengan memberikan kiat-kiat pengambilan gambar di berbagai situasi. Hasil dari pelatihan ini telah dipraktikkan oleh para pemuda karang taruna Tunas Harapan dan video yang dihasilkan telah ditunjukkan serta dinilai oleh tim PKM. Tim PKM juga menekankan bahwa video yang dibuat tidak berbau politik atau memuat unsur SARA. Video tersebut diharapkan memuat budaya dan kearifan lokal serta dapat menjadi perekat persaudaraan antarpemuda di Kelurahan Ngentakrejo.

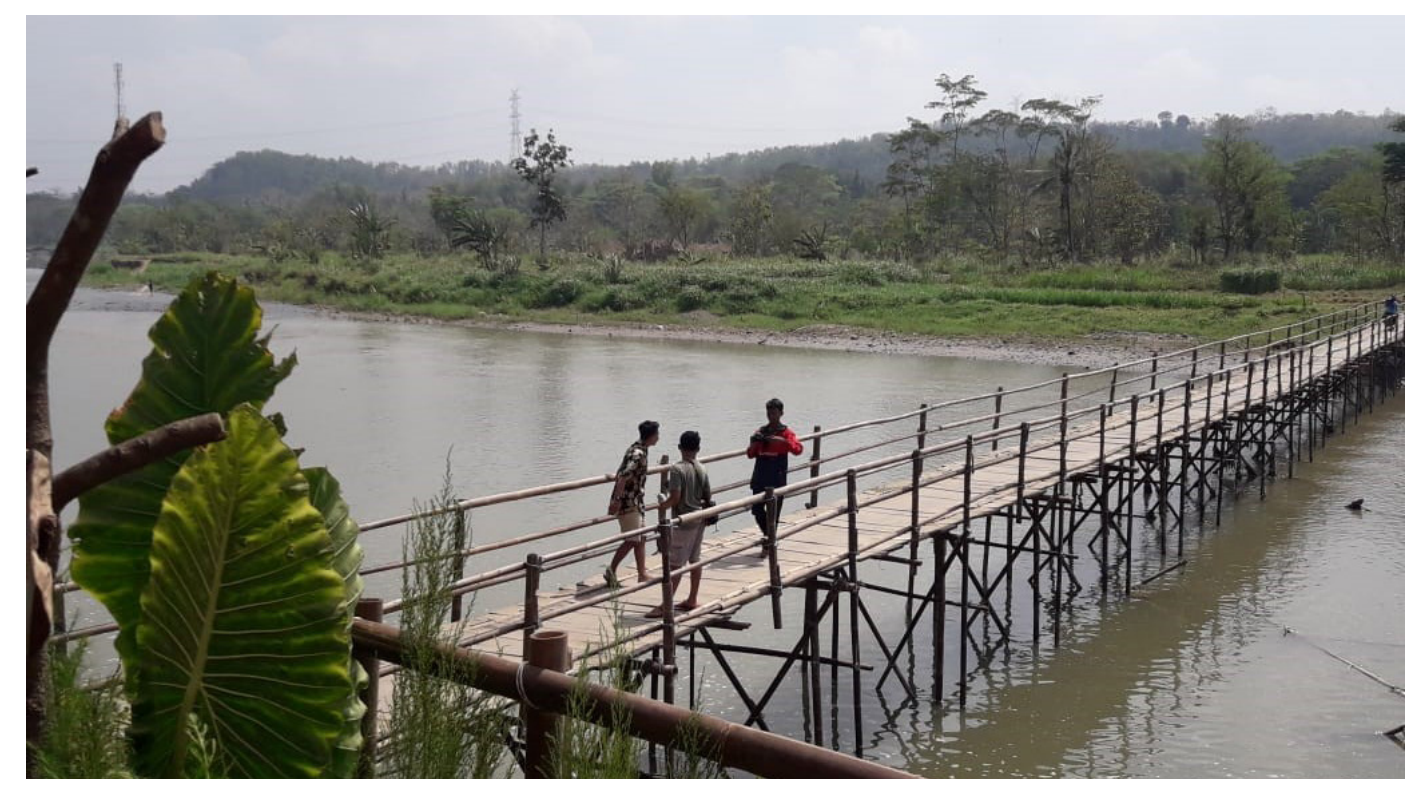

Gambar 1. Proses pelatihan pembuatan video di lapangan. 


\section{Pembuatan Video Kolaboratif}

Proses pembuatan video kolaboratif sepenuhnya dilakukan oleh pemuda karang taruna yang terlibat dalam kegiatan. Tim PKM memberikan hadiah kepada tiga video terbaik untuk menarik minat dan menambah semangat serta keseriusan pemuda dalam pembuatan video. Proses koordinasi pembuatan video dilakukan melalui grup WhatsApp. Selain sebagai sarana koordinasi, grup tersebut juga digunakan untuk berbagi dokumentasi proses penyelesaian video kolaboratif

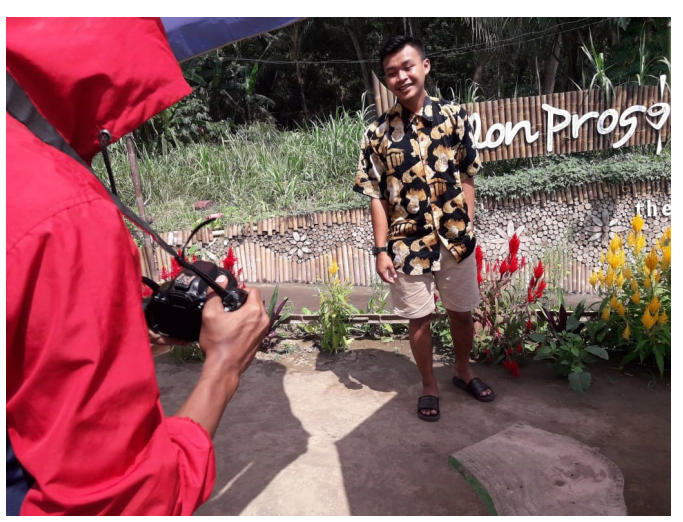

Gambar 2. Praktik pembuatan video oleh para peserta pelatihan. dari peserta kegiatan. Video kolaboratif mengambil tema kegiatan kesenian dari warga yang merupakan hasil dari praktik pelatihan dan diharapkan dapat berkelanjutan. Dalam hal ini, kegiatan berfokus pada hal-hal yang bersifat rekreasional dan santai. Video kolaboratif mengombinasikan pada bidang musik, tari, dan seni pertunjukan yang cukup sederhana. Kelompok-kelompok kesenian yang telah ada maupun anggota yang memiliki bakat dan pengalaman kegiatan kesenian, terutama musik, tari, drama ataupun puisi, diminta untuk menjadi motor penggerak kegiatan pembuatan video kolaboratif sehingga dapat berlanjut di kemudian hari.

\section{Refleksi Capaian Program}

Program pengabdian masyarakat ini telah berhasil mendorong dan memberikan motivasi kepada para anggota karang taruna Tunas Harapan Kelurahan Ngentakrejo sehingga para pemuda dapat menghasilkan tiga video kolaboratif: "Nyawiji Dadi Siji, "Tari Gemerantang Jati”, dan "Lagu Dolanan Anak Cublak Cublak Suweng”.

Video pertama berjudul "Nyawiji Dadi Siji” (bersatu menjadi satu) yang menampilkan aktivitas berkesenian para pemuda KT Tunas Harapan dalam bidang olah vokal, tari, dan bermain alat musik. Lagu yang dinyanyikan, "Nyawiji Dadi Siji", juga merupakan karya asli para pemuda, baik musik maupun liriknya. Alat musik yang digunakan cukup beragam, yakni mulai dari gitar, bas elektrik, drum, dan kendang. Pada bagian tengah lagu diberi selingan pertunjukan tari yang dilakukan di dalam rumah dengan menggunakan kostum yang cukup menarik. Dalam video tersebut tidak hanya menampilkan keterampilan vokal dan bermusik, tetapi juga melibatkan cukup banyak kreasi dari para pemuda. Para pemuda dapat menunjukkan kemampuan seni pertunjukan dengan ekspresi gerak dan wajah yang sesuai, keterampilan merancang dan memilih kostum penari, serta keterampilan videografi yang baik mulai dari proses video hingga penyuntingan hasil video yang telah diperoleh sebelumnya.

Video kedua berjudul "Tari Gemrantang Jati” yang menampilkan tarian oleh dua orang penari dengan kostum serta topeng yang menarik dan direkam di alam terbuka. Video ini juga menjadi media ekspresi kreativitas yang baik karena merupakan perpaduan beberapa unsur seni, antara lain seni tari, seni musik, dan seni pertunjukkan. Gerakan- 
gerakan tari yang disajikan dalam video ini sangat anggun dan luwes. Beberapa anggota KT Tunas Harapan memang sudah terbiasa menampilkan pentas tarian. Program ini diharapkan dapat lebih mendorong minat pemuda untuk tetap berkreasi dan berekspresi sehingga dapat mengurangi kejenuhan, menjaga kemampuan dalam bidang seni, dan melestarikan warisan seni budaya.

Video ketiga adalah video menyanyi duet yang menampilkan satu lagu dolanan (permainan) anak, yakni lagu "Cublak Cublak Suweng". Dahulu, lagu berbahasa Jawa ini sering terdengar ketika anak-anak sedang bermain permainan tradisional cublak cublak suweng, sebuah permainan tradisional yang dilakukan secara berkelompok, dengan satu orang yang giliran jaga membungkuk (posisi bersujud) dan dikelilingi anak-anak lain dengan tujuan menebak siapa yang membawa batu atau biji. Teknik pembawaan lagu dalam video ini cukup sederhana, yaitu dengan berkaraoke atau menyanyi dengan diiringi musik yang sudah ada. Akan tetapi, pembuatan video tersebut tidak terlalu mudah karena dilakukan dari rumah masing-masing. Oleh karena itu, diperlukan kreativitas dan kecermatan, terutama untuk melakukan penyuntingan hasil akhir.

Berdasarkan pengakuan dari para anggota karang taruna yang mengikuti program tersebut, Tim PKM Departemen Antarbudaya yang mengadakan kegiatan pengabdian merasa optimis dan yakin atas hasil yang dicapai meskipun persepsi mengenai keberhasilan kegiatan pemberdayaan masyarakat perlu dibuktikan dengan keberlanjutan kegiatan dan proses-proses selanjutnya. Hal tersebut senada dengan yang dituliskan Huscroft-D’Angelo (2017:562), "Meskipun penting bagi pemuda untuk merasa yakin dan percaya diri dan merasa sudah diberdayakan, persepsi pemberdayaan tersebut saja mungkin tidak cukup." Menurutnya, perlu diadakan pembekalan dan pendampingan lebih lanjut, terutama yang berkaitan dengan keterampilan-keterampilan sosial, emosional, dan pendidikan. Hal ini terutama berkaitan dengan pemberdayaan komunitas remaja atau pemuda yang mengalami tekanan yang cukup berat dan sedang mengalami masa-masa sulit atau masa-masa transisi pemulihan terhadap suatu krisis.

\section{Penutup}

Kegiatan Pengabdian kepada Masyarakat ini dapat dikatakan telah berhasil dilakukan dengan baik melalui proses-proses yang lancar sesuai dengan rencana awal. Program ini tidak luput dari kekurangan, salah satunya disebabkan oleh akses jaringan internet yang tidak selalu lancar meskipun pada dasarnya masyarakat sasaran telah dinilai memiliki tingkat kesiapan yang tinggi. Program yang dilakukan dengan sepenuhnya daring atau jarak jauh ini memang sangat mengandalkan jaringan internet. Untuk langkah ke depan, apabila keadaan telah semakin kondusif, sebaiknya program dikombinasikan dengan pertemuan langsung (luring) antartim PKM dengan masyarakat sasaran yang menginginkan hal tersebut. Masyarakat sasaran dirasakan sangat bersemangat untuk menjalin komunikasi dengan pihak kampus dan menginginkan keberlanjutan dari program-program pengabdian. Pada masa mendatang akan semakin baik jika program kesenian dilakukan dengan lebih intensif dan dijadikan sarana untuk meningkatkan tingkat kesejahteraan masyarakat sasaran. Seperti yang telah disampaikan sebelumnya bahwa masyarakat sasaran telah memiliki grup kesenian yang dapat memberikan tambahan pendapatan sebelum masa pandemi, tetapi terhenti ketika terjadi pandemi. 
Oleh karena itu, perlu mencari solusi agar kelompok-kelompok kesenian tersebut tetap memberikan hasil secara ekonomi, misalnya melalui pertunjukan kesenian daring.

\section{Daftar Pustaka}

Dunggio, M. (2013). "Semangat dan Disiplin Kerja Terhadap Produktivitas Kerja Karyawan”. Jurnal EMBA, Volume 1 (4), hlm. 523-533.

Halodoc. (2020, April 24). "Waspada Cabin Fever Akibat Terlalu Lama di Rumah". Retrieved from Halodoc: https://www.halodoc.com/artikel/waspada-cabin-feverakibat-terlalu-lama-di-rumah

Hamid, H. (2018). Manajemen Pemberdayaan Masyarakat. Makassar: De La Macca.

Huscroft-D’Angelo, J., Trout, A. L., Lambert, M. C., \& Thompson, R. (2017). Reliability and "Validity of the Youth Empowerment Scale-Mental Health in Youth Departing Residential Care and Reintegrating into School and Community Settings". EDUCATION AND TREATMENT OF CHILDREN, Volume 40 (4), hlm. 547-570. doi:10.1353/etc.2017.0024.

KT Tunas Harapan Ngentakrejo. (n.d.) Retrieved October 29, 2020, from https://web. facebook.com/profile.php?id=100010874915000

Munandar, A., Jatmiko, R., Maizida, K. (2019). "Model Pengembangan Wawasan Multikultural bagi Angkatan Kerja". Jurnal Bakti Budaya, Volume 2 (1), hlm. 23-30.

Qotijah, S. (2020, Oktober 12). Wabah Sebagai Pemicu Kreativitas: Instajam pada Instagram. Retrieved from WRITING FOR HEALING: https://wfh.sv.ugm. ac.id/2020/10/12/wabah-sebagai-pemicu-kreativitas-instajam-pada-instagram/ 